\title{
A COMPARATIVE BIOLOGICAL STUDY, RELATED TO THE THERAPEUTICALLY EFFECTS OF PAN BREAD PROVIDED WITH SOME NATURAL FOODSTUFFS UTILIZED, ON THE EXPERIMENTAL RATS
}

Saleh, M.A.M.*; Ebtesam A. Mohamed ${ }^{\star \star}$ and Mona M. M. Doeidar ${ }^{\star \star}$

* Food Technology Research Institute, Special Food \& Nutrition Dept.

** Cairo University, Faculty of Agric., Biochem. Dept.

*** Food Technology Research Institute, Bread \& Pastries Dept.

\section{ABSTRACT}

To understand the link between some nutritional diseases and different natural sources of carbohydrates, formulated pan bread (control) was prepared and investigated in a comparative study with other formulae in which an acceptable amount of foodstuffs was introduced. These suggested foodstuffs, $3 \%$ of individual dried orange albedo layer, dried apple, dried carrot and pure citrus pectin or $1.5 \%$ of pure apple pectin, were fed to experimental rat groups, in a feeding period consisting of two stages, in addition to the other three groups. The first group was fed on basal diet and the second was fed on a hypercholesterolemic diet all around the assay period. The third group and the other six groups were fed on a hypercholesterolmic diet for 2 wk (the first stage) then completed in the second period (4 wk) by feeding the former groups on the basal diet and the latter groups on the suggested diets.

Assaying some biological parameters showed that consumption of the tested diets was associated with a significant effect on the biological tests compared to the basal diet, the hypercholesterolmic diet, control pan bread and that containing pure pectin. In general, the daily body weight gain and organs weight seemed to be lower than those of the rats fed on the hypercholesterolmic diets. Blood cholesterol fractions, TC, LDL and VLDL, blood glucose, triglycerides (TG) and liver function (GPT and GOT) were also reduced at the mid and end of the second stage. On contrary, there was a significant increment in both of HDL and feces weight around the same stage, confirming the dietary benefits achieved by the suggested diets in the current study.

Keywords: Biological assays, dietary natural sources, pure pectin.

\section{INTRODUCTION}

Carbohydrates are one of the basic and important food nutrients consumed worldwide. Sometimes, food in some countries is devoid of protein and may contain only carbohydrates and fat as the major nutrients of the diet. Certain non-communicable diseases can be avoided with the adoption of proper healthier food habits and eating food according to the need of the body. Therefore, it is necessary and almost important to know the various types of carbohydrates to enable us to decide including it in our daily food according to our health requirements (Khattak, 2002). Soluble complex carbohydrates may be helpful in the management of diabetes mellitus whereas, the insoluble complex ones may be helpful in the management of constipation, diverticulitis, hemorrhoids and large bowel cancer (Gumaa et al., 2001). Consumption of certain soluble non-starch polysaccharides (NSP), such as pectin, help to lower postprandial blood glucose and insulin responses, whereas the consumption of insoluble NSP, such as wheat bran or cellulose, are ineffective (Jenkins et al., 1978). 
Pectic substances are extracted from apple pomace, beet pulp, certain vegetable wastes and citrus peels to be used in food industry as a gelling agent. The albedo, the whitish spongy layer, of the citrus fruits layer is an essential rich source of pectin, which can represent up to $50 \%$ of the dry cell wall material. The dry albedo layer of orange contained $35.6 \%$ crude fiber and $14.3 \%$ pectin (on dry weight basis) as reported by Abu-el-Maati (1999). On the other hand, it was found that the favorite pectin natural sources contents in a formulated pan bread was found in that produced by wheat substitution levels of $3 \%$ orange albedo layer, dry apple, dry carrot and citrus pectin as well as of $1.5 \%$ apple pectin from the sensory, rheological, chemical, physical, physico-chemical and economically estimation views (Saleh et al., 2002 and Mohamed et al., 2002).

Therefore, the objectives of the present study are to in-vivo evaluate the impact of some pan bread formulated diets, manufactured by pectin-rich foodstuffs sources and wheat flour blends in relative to pure sources, on some biological assays.

\section{MATERIALS AND METHODS}

\section{Materials}

Pure citrus and apple pectin were obtained from Roch Co., Switzerland. Hard wheat flour $(72 \%$ extraction) was obtained from International Co., for Processing Grain Products (Flour land, $6^{\text {th }}$ Oct. City, Zone 3, Egypt). Fresh materials (carrots, apple and orange) and all other used materials, used in pan bread manufacturing, were obtained from local market in Dokki, Giza. All the utilized kits, serum cholesterol fraction (total cholesterol (TC), high density lipoprotein (HDL), low density lipoprotein (LDL) and very low density lipoprotein (vLDL) cholesterol), triglycerides (TG), glucose and liver function, glutamate pyruvate transaminase (GPT) and glutamate oxaloacetate transaminase (GOT), were obtained from the medical division of Alkan Co., Egypt.

\section{Methods}

\section{Diets preparation:}

The prepared tested materials, i.e., dried orange albedo layer, dried apple and dried carrot, were prepared and incorporated with the most favorite percentages substitution reported by Saleh et al., (2002), 3\% in case of orange albedo layer, apple, and carrot, with wheat flour. The wheat substitution percent was $3 \%$ and $1.5 \%$ in case of pure citrus and apple pure pectin, respectively. Such materials were blended with the other required ingredients then baked to produce the tested pan bread diets. The pan bread and hypercholesterolemic diets were formulated as described by Doeidar, (2002), and the basal diet was formulated as described by El-Askalany (2000).

\section{The biological assays:}

\subsection{The experimental animals:}

Sixty male Albino rats (Western strain) $(90 \pm 5 \mathrm{~g}$,), were obtained and individually housed in well aerated $\left(25^{\circ} \pm 5^{\circ} \mathrm{C}\right)$ cages with screen bottoms at the Research Institute of Ophthalmology, Giza, Egypt, as recommended by Otsuka et al., (1989). 


\subsection{The experimental design:}

The tested rats were divided into groups (each consisted of six rats). One group was anaesthetized and the blood samples were withdrawn as well as its organs were removed, to be represented the initial values of the tested parameters. The other groups were classified as follows:

G1: rats fed on a basal diet along all the experimental period (known as the basal group),

G2: rats fed on hypercholesterolemic diet through all the experiment period (known as the hypercholesterolemic group, $\mathrm{Hc}_{1}$-con).

The reminder rats were fed on hypercholesterolemic during the adaptation period, the first stage of the experimental period, to raise their serum cholesterol within $2 \mathrm{wk}$, then, divided into 7 groups differing in their feeding diets in the second stage, $4 \mathrm{wk}$, as follows:

G3: rats fed on basal diet (known as, $\mathrm{Hc}_{2}$-con),

G4: rats fed on the pan bread without wheat substitution (control group),

G5: rats fed on $3 \%$ dried carrot substituted pan bread (carrot group),

G6: rats fed on $3 \%$ dried apple substituted pan bread (apple group),

G7: rats fed on $3 \%$ dried orange albedo layer substituted pan bread (albedo group),

G8: rats fed on $1.5 \%$ pure apple pectin substituted pan bread (apple pectin group) and

G9: rats fed on $3 \%$ pure citrus pectin substituted pan bread (citrus pectin group).

The rats weights, in g, were monthly recorded and the total weight gain (the weight difference between the final of the experiment and the first stage one), daily weight gain (total weight gain/30), daily food intake (the food intake difference between the experiment end and the first stage one/30) and the food efficiency percent (daily weight gain*100/ daily food intake) were calculated. The feces were weekly collected and recorded. The organs weight was recorded at the start and end of the experimental and the organ/final body weight percent was calculated.

\section{The biochemical analysis :}

The withdrawn serum of each rat group was periodically individually taken to determine (as $\mathrm{mg} / 100 \mathrm{ml}$ serum) TC as recommended by Allain et al. (1974), HDL as Warnick et al. (1983), LDL as Friedewald et al. (1972), vLDL calculated as Naeem (1998), TG according to Fossati and Precipel (1982), glucose as Trinder (1969) and liver function activities (GPT and GOT as Unit/ml) according to Reitman and Frankel (1957).

\section{The statistically analysis:}

The resulted data were statistically analyzed using the analysis of variance and the differences among means of diet effects were tested for the least significance differences value (LSD) at 0.05 probability by using Duncan's multiple range test by SAS (1987) program.

\section{RESULTS AND DISCUSSION}

The nutritional value of food fiber is currently more attractive and increases the intention of many investigators to go far away in this way. It includes pectin, cellulose and hemicellulose with traces of lignin (Arslan and 
Togrul, 1996). With such point of view, the present study was carried out to estimate the therapeutic effect of some natural and pure pectin sources introduced in specified diets. Such diets were fed to hypercholesterolemic rats and their biological parameters were compared with those fed on normal (namely basal group), hypercholesterolemic rats (either along all the experiment, Hc1-con, or only within the adaptation period, Hc2-con) and traditional pan bread (known as control).

Impact of the different diets feeding on the weight measurements of the tested rat groups:

Data presented in Table (1) show that the body weight of all the rat groups increased as a result of feeding on the different tested diets all over the feeding period. On the other hand, there was an insignificant difference in the initial body weight of all the tested rats and after one week of the adaptation stage (first stage of feeding period). It could be, also, found that 2 wk of feeding the tested diets should be gone to achieve any significant difference in the rat group body weights gain. The body weight of $\mathrm{Hc}_{1}$-con group was significantly different than the basal diet along with the experimental period (within the two stages). In spite of the presence of significant differences in the body weight between $\mathrm{Hc}_{1}$-con and specific group at specific feeding period, it could be concluded, in general, that there was insignificant difference compared to the other tested rat groups. On contrary, there was a varied relation among the total weight gain of rat groups fed on the tested diet (Table 1). These results illustrate that the significant differences in the body weight may be regarded to the variation in the total and daily food intake. The daily weight gain shows a similar pattern with respect to the relation between basal and the other diets concurrent with that found by Zhao et al., (1995), who stated that a lower daily gain weight was found in animals fed on high fiber diets. The same Table shows that all the tested diets were more preferable for rats than the basal diet wherein their food intake and daily food intake were significantly higher than basal group. It means that addition of the tested materials resulted in an increment in food intake which agreed with Sosulski and Cadden (1982), who related these findings to the presence of dietary fiber. The same Table shows, also, no significant difference among all the tested diets efficiency and confirmed that the interaction of food intake (diet preference) and weight gain resulted in similar efficiency diets in spite of the variation in their feeding diet ingredients.

There was an upward increment in the feces weight of all rats fed on the different tested diets up to the end of the adaptation period, whereas, it was a downward increment within the second stage of the experiment (Table 2). The same Table shows slightly changes in feces weight among all the rats fed on the formulated diets within the adaptation period but the feces weight of such diets was significantly different than the basal diet within the same period. On contrary, all the tested rats revealed significant differences as a result of feeding on the different diets within the second stage of the feeding period. Rat feces fed on the formulated diets, specially albedo, carrot and apple, were higher and significantly different than that of the other diets, including pure pectin diets. 
J. Agric. Sci. Mansoura Univ., 33 (1), January, 2008

T1-2

335 
Therefore, such suggested diets could be considered as healthy foods based on the conclusion of Eastwood and Morries (1992), who stated that the biological effects of dietary fiber along with the intestine and colon may be useful in modulation of absorption in the fore gut, modification of stool metabolism, inducement of fecal fermentation and increase in stool weight. NSP, also, increase the fecal bile acid excretion through increasing the 7hydrolase (EC 1.14.13.17) activity enzyme, which is the limiting step in the conversion of cholesterol to bile acids in the liver (Ide et al., 1990).

It was also observed that other dietary NSP increase the 7- $\alpha$ hydrolase activity in the rat liver and decreased the bile acid pool (Arjmandi et al., 1992). There was a positive relation between organ (heart, liver, kidney and spleen) weights and body weight, i.e. the body weight increased, the organ weight of the same rat group increased (Tables 1and 2). These results agreed with those of Kahlon et al., (1993). The organs weights of all the tested groups, at the experimental end, were significantly different than that of the basal diet group. On the other hand, the highest organs weight values was noticed in Hc1-con group, followed by the tested diets (Hc2-con, control, carrot, apple, albedo, apple pectin and citrus pectin) and the lowest value was noticed in the basal diet. The individual organ/final body weight \% of rat groups at the feeding period end seemed to be the same pattern of the corresponding organ weight ones which was previously discussed.

\section{Impact of the different diets feeding on the cholesterol profile of the} tested rat groups:

The increase in HDL and decrease in LDL achieved by the diets may be of particular importance in the light of the evidence that the occurrence of cardiovascular diseases (CVD) is strongly related to decrease in HDL cholesterol (Assmann and Schulte, 1992) and increase in LDL cholesterol (Grundy, 1990). Therefore, serum cholesterol profile (TC, HDL, LDL and $v L D L)$ of rats fed on the tested diets is given in Table (3).

It was found that both of TC and VLDL of the basal diet group serum were slightly upwarded within the feeding period, whereas, a detectable decrement in HDL and increment in LDL was noticed. As a result of the feeding on the hypercholesterolemic diets during the adaptation period, a dramatically increment could be noticed in TC, LDL and VLDL, whereas, a dramatically decrement was found in the HDL within the same period. A slight change in those parameters (TC, HDL, LDL and VLDL) was found in case of $\mathrm{Hc}_{1}$-con within the second stage of the experimental period. The other suggested diets revealed a high decrement in TC, LDL and VLDL, as a result of the second stage of feeding. On contrary, feeding of such suggested diets led to a detectable increment of HDL due to the same feeding stage. These results agreed with that found by El-Bastawesy and Hareedy (2004).It simply means that the harmful changes in the first stage of adaptation period, feeding on the hypercholesterolemic diet, was healthy modified by the second stage of the experiment, feeding on the suggested diets. These results are concurrent with that observed by Gumaa et al., (2001) who regarded such effect to the high viscosity of dietary fiber contents in the suggested diets (Filder, 1995) and to the dietary NSP which can alter the hepatic LDL receptor activity (Norum, 1992). 
Table (3): Effect of feeding on the different suggested diets on the cholesterol profile $(\mathrm{mg} / 100 \mathrm{ml})$ in serum of different rat groups.

\begin{tabular}{|c|c|c|c|c|c|c|c|c|}
\hline \multirow{3}{*}{$\begin{array}{l}\text { Rat } \\
\text { groups* }\end{array}$} & \multicolumn{4}{|c|}{ Total cholesterol (TC) } & \multicolumn{4}{|c|}{ High density lipoprotein (HDL) } \\
\hline & \multirow{2}{*}{$\begin{array}{l}\text { Zero } \\
\text { time }\end{array}$} & \multirow{2}{*}{$\begin{array}{c}1^{\text {st }} \\
\text { stage } \\
2^{\text {nd }} \\
\text { week }\end{array}$} & \multicolumn{2}{|c|}{$\begin{array}{l}\text { The second } \\
\text { stage }\end{array}$} & \multirow{2}{*}{$\begin{array}{l}\text { Zero } \\
\text { time }\end{array}$} & \multirow{2}{*}{\begin{tabular}{|c|}
$1^{\text {st }}$ stage \\
$2^{\text {nd }}$ week \\
\end{tabular}} & \multicolumn{2}{|c|}{$\begin{array}{l}\text { The second } \\
\text { stage }\end{array}$} \\
\hline & & & $\begin{array}{c}2^{\text {nd }} \\
\text { week }\end{array}$ & $4^{\text {th }}$ week & & & $\begin{array}{c}2^{\text {nd }} \\
\text { week }\end{array}$ & $4^{\text {th }}$ week \\
\hline $\mathbf{G 1}$ & $94.4^{\mathrm{a}}$ & $96.20^{b}$ & $100.00^{\mathrm{g}}$ & $102.00^{g}$ & $69.3^{a}$ & $55.0^{a}$ & $42.70^{f}$ & $55.00^{b}$ \\
\hline G2 & $94.4^{\mathrm{a}}$ & $244.65^{a}$ & $246.00^{a}$ & $251.00^{a}$ & $69.3^{a}$ & $38.7^{b}$ & $34.63^{h}$ & $40.70^{g}$ \\
\hline G3 & $94.4^{a}$ & $244.65^{a}$ & $156.09^{b}$ & $155.00^{b}$ & $69.3^{a}$ & $38.7^{b}$ & $38.70 \mathrm{~g}$ & $40.10^{g}$ \\
\hline G4 & $94.4^{\mathrm{a}}$ & $244.65^{a}$ & $143.31^{c}$ & $125.22^{c}$ & $69.3^{a}$ & $38.7^{b}$ & $42.70^{f}$ & $42.80^{f}$ \\
\hline G5 & $94.4^{a}$ & $244.65^{a}$ & $126.60^{e}$ & $114.80^{d}$ & $69.3^{a}$ & $38.7^{b}$ & $44.70^{\mathrm{e}}$ & $46.85^{e}$ \\
\hline G6 & $94.4^{\mathrm{a}}$ & $244.65^{a}$ & $133.30^{d}$ & $105.50^{f}$ & $69.3^{a}$ & $38.7^{b}$ & $50.90^{c}$ & $57.03^{a}$ \\
\hline G7 & $94.4^{a}$ & $244.65^{a}$ & $116.60^{f}$ & $94.40^{\mathrm{h}}$ & $69.3^{a}$ & $38.7^{b}$ & $59.70^{b}$ & $48.89^{c}$ \\
\hline G8 & $94.4^{\mathrm{a}}$ & $244.65^{a}$ & $133.30^{d}$ & 113.80 de & $69.3^{a}$ & & $62.47^{a}$ & $55.00^{b}$ \\
\hline & $94.4^{\mathrm{a}}$ & $244.65^{a}$ & $133.30^{d}$ & 11 & $69.3^{a}$ & $38.7^{b}$ & $48.89^{d}$ & $47.87^{d}$ \\
\hline \multirow{3}{*}{$\begin{array}{l}\text { Rat } \\
\text { groups* }\end{array}$} & \multicolumn{4}{|c|}{ Low density lipoprotein (LDL) } & \multicolumn{4}{|c|}{$\begin{array}{c}\text { Very low density lipoprotein } \\
\text { (vLDL) }\end{array}$} \\
\hline & \multirow{2}{*}{$\begin{array}{l}\text { Zero } \\
\text { time }\end{array}$} & $\begin{array}{c}1^{\text {st }} \\
\text { stage }\end{array}$ & \multicolumn{2}{|c|}{$\begin{array}{l}\text { The second } \\
\text { stage }\end{array}$} & \multirow{2}{*}{$\begin{array}{l}\text { Zero } \\
\text { time }\end{array}$} & e] & \multicolumn{2}{|c|}{$\begin{array}{c}\text { The second } \\
\text { stage }\end{array}$} \\
\hline & & $\begin{array}{c}2^{\text {nd }} \\
\text { week }\end{array}$ & $\begin{array}{c}2^{\text {nd }} \\
\text { week }\end{array}$ & reek & & eek & $\begin{array}{c}2^{\text {nd }} \\
\text { week }\end{array}$ & $4^{\text {th }}$ week \\
\hline G1 & $13.22^{\mathrm{a}}$ & $28.83^{b}$ & $44.5^{\mathrm{g}}$ & $33.00^{f}$ & $11.852^{a}$ & $12.37^{b}$ & $12.80^{i}$ & $14.00^{\mathrm{e}}$ \\
\hline G2 & $13.22 \mathrm{a}$ & $178.95^{a}$ & $177.77^{a}$ & $174.74^{\mathrm{a}}$ & $11.852^{a}$ & 27 & 33. & $35.55^{a}$ \\
\hline G3 & $13.22 \mathrm{a}$ & $178.95^{a}$ & $91.79^{b}$ & $90.90^{b}$ & $11.852^{a}$ & 27. & 25. & $24.00^{b}$ \\
\hline G & $13.22^{a}$ & $178.95^{a}$ & $77.15^{\mathrm{c}}$ & $62.42^{c}$ & $11.852^{a}$ & 27 & $23.46^{c}$ & $20.00^{c}$ \\
\hline G & $13.22^{a}$ & $178.95^{a}$ & $62.90^{\mathrm{e}}$ & $51.95^{d}$ & $11.852^{a}$ & 27. & $19.00^{f}$ & $13.60^{g}$ \\
\hline G & $13.22^{a}$ & $178.95^{a}$ & $66.20^{d}$ & $33.27^{f}$ & $11.852^{a}$ & 27 & $16.20^{h}$ & $15.20^{d}$ \\
\hline G & $13.22^{a}$ & $178.95^{a}$ & $39.70^{h}$ & $31.65^{f}$ & $11.852^{a}$ & $27.00^{\mathrm{a}}$ & $17.20^{\mathrm{g}}$ & $13.86^{f}$ \\
\hline G & 22 a & $178.95^{a}$ & $51.23^{f}$ & $43.60^{e}$ & $11.852^{\mathrm{a}}$ & $27.00^{\mathrm{a}}$ & 19. & $15.20^{d}$ \\
\hline & 22 a & $178.95^{a}$ & $65.41^{d}$ & $50.73^{d}$ & $11.852^{a}$ & $27.00^{a}$ & $17.60^{f}$ & $13.60^{g}$ \\
\hline & & & & & & & & 5: Carro \\
\hline
\end{tabular}
at the level of $5 \%$.

The same Table shows, also, that the foodstuff pectin sources (carrot apple and albedo) in the pan bread suggested diets significantly enhanced the healthy impact (through lowered TC, LDL and vLDL and increased HDL), than the pure pectin sources (apple and citrus) rather than the pectin free source pan bread (control). Such notice may be due to that the blood cholesterol depends on the type and quality of dietary of dietary NSP eaten (Hundemer et al., 1991). The exact mechanism of action by which such components, TC, LDL and vLDL, were reduced is unclear, but Topping (1991) proposed that the reduction in the cholesterol absorption through increasing the thickness of the unstirred layer and reducing transit time in the gut, increasing the bile excretion in the feces (by binding bile acids and increasing conversion of cholesterol to bile acids), increasing the activity of 7 $\alpha$ hydrolase enzyme in the liver and finally reducing the cholesterol synthesis in the liver and small intestine, indirectly by inhibition the activity of Coenzyme 
A-reductase enzyme in the liver and small intestine via the fermentation product propionate.

Impact of the different diets feeding on the serum TG and glucose of the tested rat groups:

After 2 wk of feeding (Table 4) the tested rat groups within the adaptation period, TG in the rat serum fed on basal diet was highly significant lower than that of the other tested group which may be due to the hypercholesterolemic diet impact in the later group diets. TG of $\mathrm{Hc}_{1}$-con group possessed the highest value than that of all the other tested diet groups as a result of extending the hypercholesterolemic diet within the second stage of the in vivo assay. As changing the diet in the $\mathrm{Hc}_{2}$-con group to casein within the second stage, TG of such group was significantly lower than $\mathrm{Hc}_{1}$-con, but still significantly higher than the other suggested formulated groups. There were significant differences among such groups due to the presence of pectic substances (El-Bastawesy and Hareedy, 2004), which contribute in altering the emulsification and lipolysis of triglycerols in both stomach and duodenal medium which can alter lipid metabolism (Pasquier et al., 1996). In addition to that, feeding on such materials, rich in complex carbohydrates, enhanced the fecal bile acids excretion in rats through increasing the viscosity of the contents and small intestine and therefore might interfere with digestion and absorption of lipids (Topping et al., 1988).

Table (4): Effect of feeding on the different suggested diets on the triglycerides and glucose values in serum $(\mathrm{mg} / 100 \mathrm{ml})$ of different rat groups.

\begin{tabular}{|c|c|c|c|c|c|c|c|c|}
\hline \multirow{3}{*}{$\begin{array}{l}\text { Rat } \\
\text { groups* }\end{array}$} & \multicolumn{4}{|c|}{ Triglycerides (TG) } & \multicolumn{4}{|c|}{ Glucose } \\
\hline & \multirow{2}{*}{$\begin{array}{l}\text { Zero } \\
\text { time }\end{array}$} & \multirow{2}{*}{$\frac{1^{\text {st }} \text { stage }}{2^{\text {nd }} \text { week }}$} & \multicolumn{2}{|c|}{ The second stage } & \multirow{2}{*}{$\begin{array}{l}\text { Zero } \\
\text { time }\end{array}$} & \multirow{2}{*}{$\frac{1^{\text {st }} \text { stage }}{2^{\text {nd }} \text { week }}$} & \multicolumn{2}{|c|}{ The second stage } \\
\hline & & & $2^{\text {nd }}$ week & $4^{\text {th }}$ week & & & $2^{\text {nd }}$ week & $4^{\text {th }}$ week \\
\hline G1 & $59.26^{a}$ & $61.85^{b}$ & $64.00^{i}$ & $70.00^{f}$ & $84.8^{a}$ & $91.63^{b}$ & $95.00^{h}$ & $100.5^{i}$ \\
\hline & $59.26^{a}$ & $135.00^{a}$ & $168.00^{a}$ & $177.80^{a}$ & $84.8^{a}$ & $169.69^{a}$ & $172.72^{a}$ & $175.60^{a}$ \\
\hline G3 & $59.26^{a}$ & $135.00^{a}$ & $128.00^{b}$ & $120.00^{b}$ & $84.8^{a}$ & $169.69^{a}$ & $160.60^{\mathrm{b}}$ & $157.57^{b}$ \\
\hline G4 & $59.26^{a}$ & $135.00^{a}$ & $117.30^{c}$ & $100.00^{c}$ & $84.8^{a}$ & $169.69^{a}$ & $151.51^{c}$ & $140.90^{c}$ \\
\hline$G$ & $59.26^{a}$ & $135.00^{a}$ & $95.00^{\mathrm{e}}$ & $80.00^{d}$ & $84.8^{a}$ & $169.69^{a}$ & $143.93^{f}$ & $137.87^{d}$ \\
\hline G6 & $59.26^{a}$ & $135.00^{a}$ & $81.00^{h}$ & $76.00^{e}$ & $84.8^{a}$ & $169.69^{a}$ & $145.45^{e}$ & $133.33^{e}$ \\
\hline G7 & $59.26^{a}$ & $135.00^{a}$ & $86.00^{g}$ & $69.30^{g}$ & $84.8^{a}$ & $169.69^{a}$ & $139.39^{g}$ & $124.24^{g}$ \\
\hline G8 & $59.26^{a}$ & $135.00^{a}$ & $98.00^{d}$ & $76.00^{e}$ & $84.8^{a}$ & $169.69^{a}$ & $148.48^{d}$ & $121.21^{h}$ \\
\hline G9 & $59.26^{a}$ & $135.00^{a}$ & $88.00^{f}$ & $68.00^{h}$ & $84.8^{a}$ & $169.69^{a}$ & $145.45^{e}$ & $130.30^{f}$ \\
\hline
\end{tabular}

* G1: Basal G2: Hc1-con G3: Hc2-con G4: Control G5: Carrot

G6: Apple G7: Albedo G8: Apple pectin G9: Citrus pectin

-Values followed by the same letter within the same column are not significantly different at the level of $5 \%$.

The glucose amount in serum of the tested rats fed on the different assayed diets possessed the same pattern which was found in case of TG all over the experimental period (the first and second stages) as illustrated in Table (4). Such results are confirmed with those found by Galibis et al. (1992), who regarded this model to that the nutrients fed simultaneously seemed to exert independent and mostly distinct effects on glucose metabolism or probably due to hormonal responses. The variation in the effect of the tested diets may be due to the consumption amount of certain soluble NSP (such as pectin and guar gum) shown to lower postprandial blood glucose and insulin responses, whereas, the insoluble NSP (such as 
wheat bran and cellulose) are ineffective (Jenkins et al., 1978). In spite of that the involved mechanisms are not established, Khattak (2002) summarized the proposed mechanisms of action in which the NSP reduced blood glucose through one or more of four pathways. The first is through lowering the diffusion rate of various carbohydrates in the small intestine via lowering the rate of absorption of the products of digestion. The second is through retarding the rate of passage of the contents of the stomach into the duodenum. The third is through lowering the rate of hydrolysis of polysaccharide in the upper small intestine by reducing the contact of nutrients and finally through alter the release of gut hormones.

Impact of the different diets feeding on the liver functions of the tested rat groups:

There was a slight minor increment of liver functions, serum GOT and GPT, as a result of feeding rats on the basal diet along with the in vivo experimental assay, first and second stages, as shown in Table (5). Feeding the other tested groups on the hypercholesterolemic diet within the adaptation period (2 wk) resulted in a noticeable increment in serum GOT and GPT activities. These results were due to that the hypercholesterolemic diet which significantly stimulated such activities as reported by Ahmed et al. (1987). Such increment was extended in $\mathrm{Hc}_{1}$-con rat group as a result of feeding on hypercholesterolemic diet along with the second stage of experiment. It could be due to the aforementioned reasons, but in case of $\mathrm{Hc}_{2}$-con group, it could be noticed that both of GOT and GPT slightly decreased due to the change of rat diets from hypercholesterolemic to basal diet. On the other hand, the decrement was more detectable in the other tested rat groups due to the change in the diet within the second stage of the experiment (Table 5).

Table (5): Glutamate pyruvate transaminase (GPT) and glutamate oxaloacetate transaminase (GOT) activities in serum (U/ml), of different rat groups fed on the different suggested diets.

\begin{tabular}{|c|c|c|c|c|c|c|c|c|}
\hline \multirow{3}{*}{$\begin{array}{l}\text { Rat } \\
\text { groups* }\end{array}$} & \multicolumn{4}{|c|}{ Glutamate pyruvate transaminase } & \multicolumn{4}{|c|}{ Glutamate oxaloacetate transaminase } \\
\hline & \multirow{2}{*}{$\begin{array}{l}\text { Zero } \\
\text { time }\end{array}$} & \multirow{2}{*}{$\begin{array}{l}1^{\text {st }} \text { stage } \\
2^{\text {nd }} \text { week }\end{array}$} & \multicolumn{2}{|c|}{ The second stage } & \multirow{2}{*}{$\begin{array}{l}\text { Zero } \\
\text { time }\end{array}$} & \multirow{2}{*}{$\begin{array}{l}1^{\text {st }} \text { stage } \\
2^{\text {nd }} \text { week }\end{array}$} & \multicolumn{2}{|c|}{ The second stage } \\
\hline & & & $2^{\text {nd }}$ week & $4^{\text {th }}$ week & & & $2^{\text {nd }}$ week & $4^{\text {th }}$ week \\
\hline G1 & $39.6^{a}$ & $40.0^{b}$ & $40.5^{\mathrm{h}}$ & $41.0^{g}$ & $22.0^{\mathrm{a}}$ & $23.0^{b}$ & $23.0^{f}$ & $24.0^{f}$ \\
\hline G2 & $39.6^{a}$ & $53.8^{a}$ & $59.6^{a}$ & $73.0^{\mathrm{a}}$ & $22.0^{a}$ & $36.0^{a}$ & $45.0^{a}$ & $58.0^{a}$ \\
\hline G3 & $39.6^{a}$ & $53.8^{a}$ & $51.5^{b}$ & $50.0^{b}$ & $22.0^{a}$ & $36.0^{a}$ & $34.0^{b}$ & $32.0^{b}$ \\
\hline G4 & $39.6^{a}$ & $53.8^{a}$ & $49.5^{c}$ & $47.0^{c}$ & $22.0^{a}$ & $36.0^{a}$ & $31.0^{c}$ & $30.0^{c}$ \\
\hline G5 & $39.6^{a}$ & $53.8^{a}$ & $48.0^{d}$ & $42.0^{\mathrm{e}}$ & $22.0^{a}$ & $36.0^{a}$ & $27.0^{d}$ & $25.0^{\mathrm{e}}$ \\
\hline G6 & $39.6^{a}$ & $53.8^{a}$ & $47.0^{\mathrm{e}}$ & $41.5^{\text {ef }}$ & $22.0^{a}$ & $36.0^{a}$ & $27.0^{d}$ & $26.0^{d}$ \\
\hline G7 & $39.6^{a}$ & $53.8^{a}$ & $45.0^{\mathrm{g}}$ & $39.0^{h}$ & $22.0^{a}$ & $36.0^{a}$ & $26.0^{\mathrm{e}}$ & $24.0^{f}$ \\
\hline G8 & $39.6^{a}$ & $53.8^{a}$ & $48.0^{d}$ & $44.6^{d}$ & $22.0^{a}$ & $36.0^{a}$ & $27.0^{d}$ & $26.0^{d}$ \\
\hline G9 & $39.6^{a}$ & $53.8^{a}$ & $46.0^{f}$ & $42.6^{\text {de }}$ & $22.0^{a}$ & $36.0^{a}$ & $26.0^{\mathrm{e}}$ & $25.0^{e}$ \\
\hline & 7 & $\mathrm{Hc}_{1}$-con & 0 & & & & & Carro \\
\hline
\end{tabular}

G6: Apple G7: Albedo G8: Apple pectin G9: Citrus pectin

-Values followed by the same letter within the same column are not significantly different at the level of $5 \%$.

GOT and GPT activities of rat groups fed on the suggested diets were significantly lower compared to the previous groups. These findings confirmed the healthy roles of pectin in lowering the GOT and GPT activities 
as reported by Hancakowski et al. (2001). Those findings are concurrent with that found by Khalili et al. (2002); Amer (2002) and El-Bastawesy and Hareedy (2004), who reported that dietary fiber and pectin possessed a positive effect on lowering GOT and GPT which greatly affected the liver function. It could be also, found that the albedo diet possessed a significant therapeutic role in lowering the GOT and GPT activities than the other suggested diets, including pure apple and citrus.

Consequently, as a result of the beneficial impact of utilization of foodstuffs pectin sources, it should be involved as an important constituent in our daily mail and it can be adopted for management of certain diseases provided that it is used in proper amount. It is, also, necessary and of utmost importance to know the various types of carbohydrates in the suggested diets to enable us to decide to include carbohydrates in our daily food according to our health requirements. It is finally concluded that it is not necessary to know all the community need but at least those who are associated with nutrition and health management must know the beneficial as well as the harmful effects of carbohydrates (Khattak, 2002).

\section{REFERENCES}

Abu-el-Maati, S.M. (1999). Orange processing wastes as source of dietary fiber in white pan bread. Zagazig J. Agric. Res. 26:381.

Ahmed, F. A.; El-Desoky, G. E.; El-Saadawy, S. S. and Ramadan, M.E. (1987). Carbohydrates and lipid changes in rats administrated certain and natural food colors. Minia J. Aaric. Res. and Dev., 9:1101.

Allain, C.C.; Poon, L. S.; Chan, C. S.; Richmond, W. and Fu, P. C. (1974). Enzymatic determination of total serum cholesterol. Clin. Chem. 20:470.

Amer, M.M. (2002). Chemical, technological and biological evaluation of dietary fibers of apple pomace. M.Sc. Thesis, Food Sci. and Tech. Dept., Fac. of Agric., Cairo Univ.,

Arjmandi, B.H.; Ahn, J.; Nathani, S. and Reeves, R.B. (1992). Dietary soluble fiber and cholesterol affect serum cholesterol concentrations, hepatic portal venous short chain fatty acids concentrations and fecal sterol excretion in rats. J. Nutr., 122:246.

Arslan, N. and Togrul, H. (1996). Filtration of pectin extract from grapefruit peel and viscosity of pectin solutions. J. Food Engineering, 27:191.

Assmann, G. and Schulte, H. (1992). Relation of high density lipoprotein cholesterol and triglycerides to incidence of atherosclerotic artery disease. Am. J. Cardiol., 70:733.

Doeidar, M.M.M. (2001). Chemical and physical studies on some natural resources used in improving bakery products. Ph.D. Thesis, Biochem. Dept., Fac. of Agric., Cairo Univ.

Eastwood, M.A. and Morries, A. (1992). Physical properties of dietary fiber that influence physiological function : a model for polymers the gastrointestinal tract. Am. J. Nutr., 55:346. 
EL-Askalany, S. A. H., (2000). Evaluation of using agricultural wastes to produce low calories food. M. Sc. Thesis, Institute of Environmental studies and Researches. Ain shams Univ.

El-Bastawesy, Amal M. and Hareedy, Lobna A. (2004). Utilization of food processing wastes as sources of dietary fibers and its effect on lipoproteins in rats. Egypt. J. Agric. Res., 82:1311.

Filder, N. (1995). The effect of viscosity of intestinal contents on nutrient absorption. Zbornik-Biotehniske-Fakultete-Univerze- V - Kmetijstuo, 66,99. (Abstract).

Fossati, P. and Precipel, L. (1982). The determination of triglyceride using enzymatic methods. Clin. Chem. 28:2077.

Friedewald, W. T.; Levy, R. I. and Fredrickson, S. D. (1972). Estimation of the concentration of low-density lipoprotein cholesterol without the use of the preoperative ultracentrifuge. Clin Chem. 18:499.

Galibis,L. ;Jacques,H. ;Montminy,C. ; Bergeron, N. and Lavigne,c. (1992). Independent effects of protein and fiber sources on glucose and cholesterol metabolism in the rat. Nutr. Res., 12:643.

Grundy, S.M. (1990). Cholesterol and atherosclerosis. Diagonosis and treatment. Ed. Lippincott, J. B., Philadelphia, Gower Medical Publishing, New York.

Gumaa, A.Y.; Seifelnasr, E.; Al-Rawashdeh, O.; Orban, J.I.; Patterson, J. A.and Nour, A.Y.M. (2001). Physiological effects and health benefits of feeding oligosaccharides. Vet. Med. J. Giza, 49:163.

Hancakowski, P.; Szymczyk, B. and Szczurek, W. (2001). Effect of different dietary fibers and protein on serum cholesterol level in rats. Annals of Animal Sci., 1:113.

Hundemer, J.K.; Nabar, S.P.; Shriver, B.J. and Foman, L.P. (1991). Dietary fiber sources lower blood cholesterol in C57BL/6 mice. J. Nutr., $121: 1360$.

Ide, T.; Horii, M.; Yamamoto, T. and Kawashima, M. (1990). Contrasting effects of water soluble and water insoluble dietary fibers on bile acids conjungation and taurine metabolism in rats. Lipids, 25:335.

Jenkins, D.J.A.; Wolever, T.M.S.; Leeds, A.R.; Gassul, M.A.; Haisman, P.J.; Goh, D.V.; Metz, G.L. and Alberti, K.G. (1978). Dietary fiber; fiber analogous and glucose tolerance importance of viscosity. Br. Med. J., $1: 1392$.

Kahlon , T . S .;Chow ,F . I . ;Knuckles ,B . E . and Chiu , M .M . (1993). Cholesterol - lowering effects in hamsters of $B$ - glucan enriched fraction, dehulled whole barley, rice bran, and oat and their combinations. Cereal Chem., 70: 455.

Khalii, F.; Sadek, M. and Barakat, L. (2002). Dietary effect on inulin and pectin on apparent digestibility, blood glucose and lipid profile in rats. Proceeding of the $1^{\text {st }}$ Arab Mansoura Conference of Food and Dairy Science and Technology, 1-3 Oct., Fac. of Agric., Mansoura Univ., Egypt.

Khattak, M.M.A.K.(2002). Physiological effects of dietary complex carbohydrates and its metabolites role in certain diseases. Pakistan J. of Nutri., 1:161. 
Mohamed, E. A.; Saleh, M.A.M. and Mona, M. M. Doeidar (2002). Natural source of pectin impacts on the chemical and physical properties of pan bread. 1st., Arab Mansoura Conference of Food and Dairy Science \& Technology. pp. 243-252. 1-3 October,2002. Faculty of Agriculture, Mansoura University, Egypt.

Naeem, M. A. M. (1998). Evaluation of nutritional status of cornory atherosclerotic patients attending A.S.U.S.H. M.Sc. Thesis. Department of nutrition and food science, Menoufia Univ.

Norum, K. R. (1992). Dietary fats and blood lipids. Nutr. Rev., 50:30.

Otsuka, M.; Satchithanandam, S.; and Calvert, R. J., (1989). Influence of meal distribution of wheat bran on fecal bulk, gastrointestinal transit time and colonic thymidine kinase activity in the rat. Am. Clin. Nutr. J. 119:566.

Pasquier, B.; Armand, M.; Guillon , F.; Castelain, C.; Borel, P.; Barry, JL.; Pieroni, G.and Lairon, D. ( 1996 ) . Viscous Soluble dietary fibers alter emulsification and lipolysis of triglysis of trigycerols in dustdenal medium in vitro. J.Nutr. Biochem. 7: 293.

Reitman, S. and Frankel, S. (1957). A colorimetric method for the determination of serum glutamic oxaloacetic and glutamic pyruvic transaminases. Am. J. Clin. Path. 28:56.

Saleh, M.A.M. ; Mohamed, E. A.; and Mona, M. M. Doeidar (2002). Sensory, rheological and economic evaluation of pan bread produced by specified levels of different natural sources of pectin. 1 st., Arab Mansoura Conference of Food and Dairy Science \& Technology. pp. 155-166. 1-3 October,2002. Faculty of Agriculture, Mansoura University, Egypt.

SAS, (1987). Statistical Analysis System. Release 6.03. SAS Institute Inc., Carry, NC, USA

Sosulski, F.w. and Cadden, A.M. (1982). Composition and physiological properties of several sources of dietary fiber. J. Food Sci., 47:1472.

Topping, D.L. (1991). Soluble fibers: Effect on plasma cholesterol and colonic fermentation. Nutr. Rev., 49:195.

Topping, D.L.; Oakenfull, D.; Trimble, R.P. and Illman, R.J. (1988). A viscous fiber (methyl cellulose) lower blood glucose and plasma triacylglycerol and increases liver glycogen independently of volatile fatty acids production in rats. Br. J. Nutr., 59:21.

Trinder, P. (1969). Determination of glucose in blood using glucose oxidase with an altemative oxygen acceptor. Am. Clin. Biochem. 6:24.

Warnick, G. R.; Benderson, V. and Albers, N. (1983). Selected method. Clin. Chem. 10:91.

Zhao, X.; Jorgensen, H.; and Eggum, B. O. (1995). The influence of dietary fiber on body composition visceral organ weight, digestibility and energy balanced in rats housed in different thermal environments. Brit. J. Nutr. 73:687. 


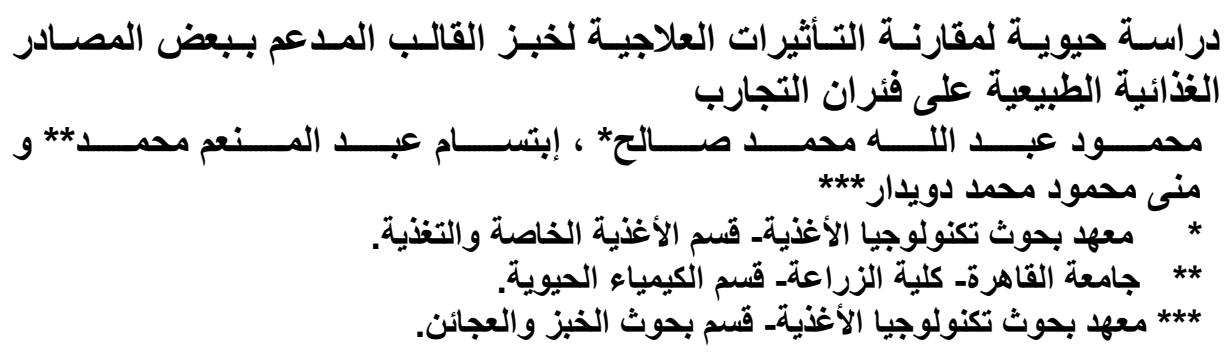

تم اجر اء الدر اسه الحاليه من أجل التعرف علي مدى الإرتباط بين بعض الأمر اض الغذائيه

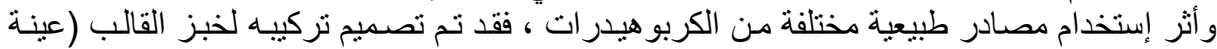

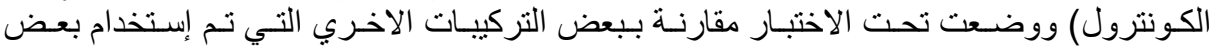

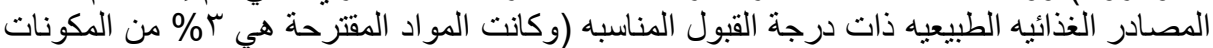

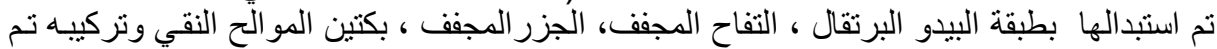

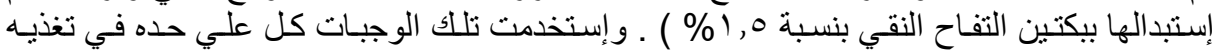

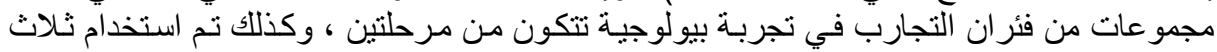

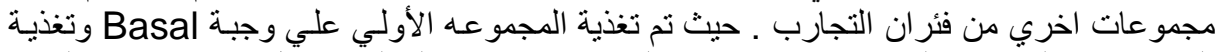

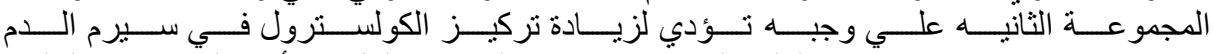
وبرypercholesterolemic

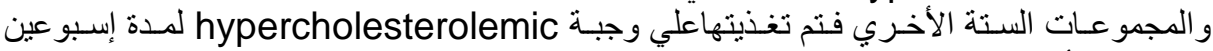

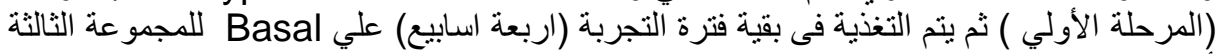

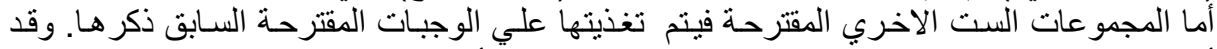

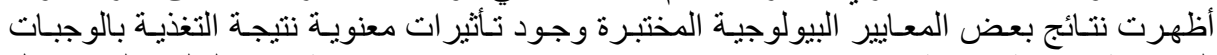

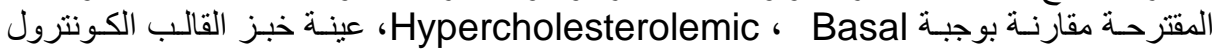

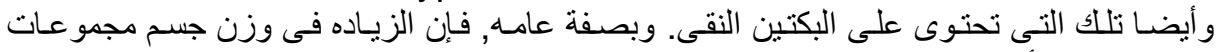

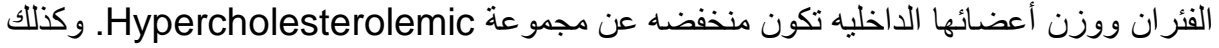

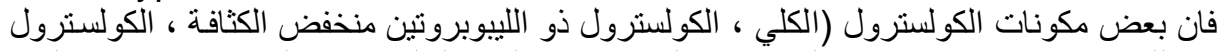

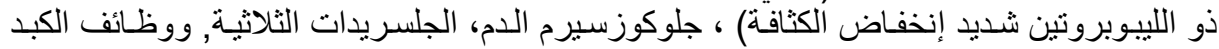

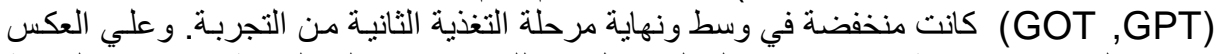

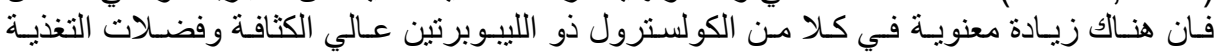

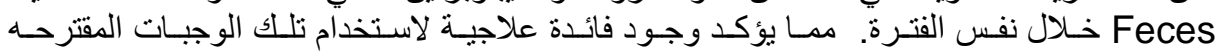
المستخدمة في الدراسة. 
Table (1): Effect of feeding on the different suggested diets on the body weight, daily body weight gain, daily food intake and food efficiency ratio of rats.

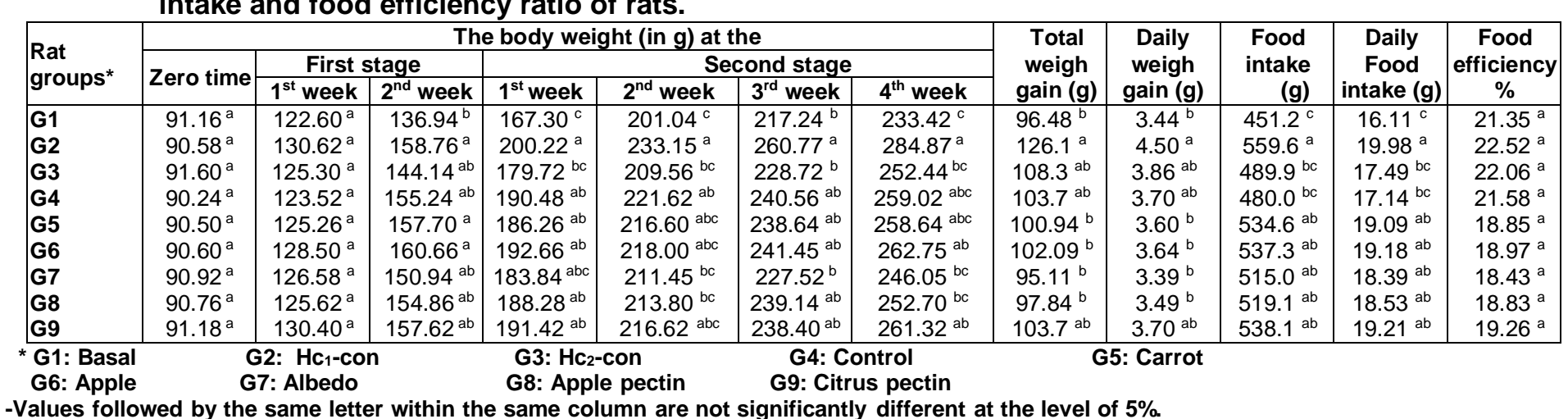

\section{Table (2): Feces and organs weights of different rat groups fed on the different suggested diets.}

\begin{tabular}{|c|c|c|c|c|c|c|c|c|c|c|c|c|c|c|}
\hline \multirow{3}{*}{$\begin{array}{l}\text { Rat } \\
\text { groups }\end{array}$} & \multicolumn{6}{|c|}{ Feces weight(g) at the end of } & \multicolumn{8}{|c|}{ Organs rats weight at the feeding period end } \\
\hline & \multicolumn{2}{|c|}{ The first stage } & \multicolumn{4}{|c|}{ The second stage } & \multicolumn{4}{|c|}{ Organs weight (g) } & \multicolumn{4}{|c|}{ Organ/final body weight (\%) } \\
\hline & $1^{\text {st }}$ week & $2^{\text {nd }}$ week & $1^{\text {st }}$ week & $2^{\text {nd }}$ week & $2^{\text {rd }}$ week & $4^{\text {th }}$ week & Heart & Liver & Kidney & Spleen & Heart & Liver & Kidney & Spleen \\
\hline G1 & & & & & & & $0.25^{i}$ & $2.81^{1}$ & $0.49^{9}$ & $0.17^{\dagger}$ & $0.28^{f}$ & $3.10^{e}$ & $0.54^{i}$ & $0.19^{f}$ \\
\hline G2 & $9.07^{\mathrm{b}}$ & $10.04^{b}$ & $12.84^{\dagger}$ & $14.04^{f}$ & $14.39^{f}$ & $14.84^{f}$ & $0.68^{h}$ & $8.00^{h}$ & $1.40^{f}$ & $0.53^{e}$ & $0.29^{\text {ef }}$ & $3.43^{\text {de }}$ & $0.60^{\mathrm{cd}}$ & $0.23^{\mathrm{cd}}$ \\
\hline G3 & $10.88^{a}$ & $12.32^{\mathrm{a}}$ & $14.82^{\mathrm{e}}$ & $16.73^{e}$ & $16.81^{\mathrm{e}}$ & $16.98^{e}$ & $1.13^{\mathrm{a}}$ & $15.75^{a}$ & $2.19^{a}$ & $0.79^{\mathrm{a}}$ & $0.40^{\mathrm{a}}$ & $5.53^{\mathrm{a}}$ & $0.77^{\mathrm{a}}$ & $0.28^{a}$ \\
\hline G4 & $10.00^{a b}$ & $12.40^{\mathrm{a}}$ & $13.52^{\mathrm{ef}}$ & $14.38^{f}$ & $14.51^{\dagger}$ & $14.62^{f}$ & $0.95^{b}$ & $9.83^{b}$ & $1.81^{\mathrm{b}}$ & $0.63^{b}$ & $0.38^{\mathrm{b}}$ & $3.89^{\mathrm{b}}$ & $0.72^{b}$ & $0.25^{\mathrm{b}}$ \\
\hline G5 & $10.18^{a}$ & $12.30^{\mathrm{a}}$ & $18.37^{d}$ & $18.50^{\mathrm{b}}$ & $18.64^{\mathrm{d}}$ & $18.73^{d}$ & $0.93^{c}$ & $9.81^{\mathrm{b}}$ & $1.81^{\mathrm{b}}$ & $0.62^{b c}$ & $0.36^{c}$ & $3.79^{\mathrm{b}}$ & $0.70^{\mathrm{b}}$ & $0.24^{\mathrm{bc}}$ \\
\hline G6 & $10.22^{\mathrm{a}}$ & $12.58^{\mathrm{a}}$ & $21.54^{\mathrm{bc}}$ & $22.30^{\mathrm{bc}}$ & $22.63^{\mathrm{bc}}$ & $22.89^{b c}$ & $0.83^{d}$ & $9.20^{d}$ & $1.57^{\mathrm{d}}$ & $0.59^{d}$ & $0.32^{d}$ & $3.56^{\mathrm{cd}}$ & $0.61^{c}$ & $0.23^{\text {cd }}$ \\
\hline G7 & $10.42^{a}$ & $12.52^{\mathrm{a}}$ & $22.30^{\mathrm{ab}}$ & $23.50^{\mathrm{b}}$ & $23.95^{\mathrm{b}}$ & $24.12^{b}$ & $0.78^{f}$ & $9.43^{\circ}$ & $1.60^{c}$ & $0.61^{\mathrm{c}}$ & $0.30^{\mathrm{e}}$ & $3.59^{c}$ & $0.61^{c}$ & $0.23^{\mathrm{cd}}$ \\
\hline G8 & $10.45^{\mathrm{a}}$ & $12.36^{\mathrm{a}}$ & $23.90^{\mathrm{a}}$ & $25.50^{\mathrm{a}}$ & $25.97^{\mathrm{a}}$ & $26.20^{a}$ & $0.71^{\mathrm{g}}$ & $8.43^{g}$ & $1.42^{f}$ & $0.54^{\mathrm{e}}$ & $0.29^{\text {ef }}$ & $3.43^{\text {de }}$ & $0.58^{d}$ & $0.22^{\text {de }}$ \\
\hline G9 & $10.13^{a}$ & $12.04^{\mathrm{a}}$ & $20.50^{c}$ & $21.60^{c}$ & $21.69^{c}$ & $21.73^{c}$ & $0.80^{\mathrm{e}}$ & $8.71^{\dagger}$ & $1.49^{\mathrm{e}}$ & $0.54^{\mathrm{e}}$ & $0.32^{d}$ & $3.45^{\text {cde }}$ & $0.59^{\mathrm{cd}}$ & $0.21^{\mathrm{e}}$ \\
\hline G1 & $10.70^{a}$ & $12.01^{\mathrm{a}}$ & $21.45^{\mathrm{bc}}$ & $22.00^{b c}$ & $22.41^{b c}$ & $22.62^{\mathrm{bc}}$ & $0.78^{f}$ & $8.93^{e}$ & $1.56^{\mathrm{d}}$ & $0.58^{d}$ & $0.30^{\mathrm{e}}$ & $3.42^{\text {de }}$ & $0.60^{\mathrm{cd}}$ & $0.22^{\text {de }}$ \\
\hline
\end{tabular}

-Values followed by the same letter within the same column are not significantly different at the level of $5 \%$. 
J. Agric. Sci. Mansoura Univ., 33 (1), January, 2008 